\title{
SCHOOL PERFORMANCE AND STABILITY OF STUDENT NURSES
}

\author{
X.C. Birkenbach \\ Lecturer, \\ Dept. of Industrial and Organisational Psychology, University of Port Elizabeth
}

\section{OPSOMMING}

Die keuring van studentverpleegsters skep spesifieke probleme vir verpleegadministrateurs en skoolprestasie skyn een van die min objektiewe keurmiddels te wees. Die resultate van hierdie studie toon dat daar wel beduidende verskille bestaan met betrekking tot prestasie in skoolvakke tussen studente wat hul opleiding voltooi het en die wat hul opleiding gestaak het. Kosteimplikasies van kortdienstermynstudente wat die beroep verlaat, word bespreek.

$\mathbf{O}$ WING to a number of factors the selection of student nurses in hospitals appears to present specific problems for the nursing administrator. In the first place, nursing applicants are, with few exceptions, recruited straight from school. Consequently very little information is available in order to assess the suitability of the applicant to nursing. Furthermore, at the time of her application, the interests, ambitions and career aspirations of the scholar are still in a process of being shaped. Therefore the applicant herself is probably not in a position to make a commited career decision at this stage. Moreover, the selection ratio (i.e. the number of applicants in relation to the number of posts) is usually not very favourable. This has the result that nursing administrators cannot screen applicants effectively most of those who apply are accepted for training owing to the shortage of staff.

Within these constraints the administrator has only a few guidelines in order to make a selection decision, namely, the medical examination, character references, selection interview and the applicant's school leaving certificate.

Regarding these aids, the medical examination can screen out those applicants who are obviously not suitable from a medical point of view. Character references are generally regarded as being of very little value in improving the predictive efficiency of selection decisions (Flippo, 1976). The selection interview, especially interviews which are unstructured, can be very subjective, with resultant loss of validity of assessments. It appears, therefore, that one of the few objective aids at the disposal of nursing administrators to evaluate the suitability of nursing applicants, is the school performance of the individual as reflected by the symbols achieved for subjects studied.

Although there is a fairly widely held belief that successful performance at school is usually a good predictor of success in later work life, organisations in most cases never attempt to match these two sets of variables. Such an exercise would seem particularly desirable in the nursing profession as far as student nurses are con- cerned. Firsly, the difficulty level of the nursing curriculum has increased over time. Therefore it can be hypothesised that school achievement could be predictive of successful completion of nursing training. Furthermore, the rate of attrition of student nurses is comparatively high. Consequently, more effective screening of applicants on the basis of their school performance could result in more effective utilisation of personnel and reduction of costs.

In view of the foregoing, the present study was conducted with two aims in mind:

In the first place, to establish the nature of the relationship between school performance of student nurses and their later stability during training.

Secondly, to gain insight into the nature of attrition among student nurses with specific regard to the length of time students spent in training before terminating.

\section{Method}

\section{Samples}

The total sample consisted of 244 student nurses of whom 91 had completed their training (stayers) and 153 failed to complete the course (leavers). The leavers' group constituted persons who left nursing owing to reasons such as dissatisfaction with nursing, failing nursing examinations, or marriage. Persons who left because of medical reasons or pregnancies were not included in the study.

\section{Procedure}

All the data were gathered from school leaving cer tificates of students which gave the symbols achieved by the persons on the various subjects studied. With this information it could be determined how well stayers and leavers performed at school. For the purpose of this study, individuals who achieved $\mathrm{A}, \mathrm{B}$ or $\mathrm{C}$ symbols were considered to be "better" school performers while those who received $D, E$ or $F$ symbols were classified as "poorer" performers.

The frequencies of the data recorded were converted to percentages in order to make comparisons between 
the groups of stayers and leavers. In order to assess the significances of the percentage differences between the two groups, use was made of a nomograph developed by Lawshe and Baker (1950). This nomograph is used to calculate an omega value (w) which, when substituted in the appropriate formula, gives t-values, which indicate the significance of the differences between percentages. are not reported here. Also, in some cases, sample sizes on certain school subjects were regarded as being too small to allow meaningful interpretation. For example, symbols for Science were only available for 7 stayers and 24 leavers. Consequently these results are also not reported here.

From the information presented in the table it is ap-

TABLE 1

Percentage difference between stayers and leavers on school subjects.

\begin{tabular}{|c|c|c|c|c|c|c|}
\hline \multirow{3}{*}{$\begin{array}{l}\text { SCHOOL } \\
\text { SUBJECTS } \\
\text { English } \\
- \text { ABC } \\
- \text { DEF }\end{array}$} & \multicolumn{2}{|c|}{ STAYERS } & \multicolumn{2}{|c|}{ LEAVERS } & \multirow{2}{*}{$\begin{array}{l}\text { PERCENTAGE } \\
\text { DIFFERENCES }\end{array}$} & \multirow{2}{*}{$\begin{array}{c}\text { W } \\
\text { VALUES }\end{array}$} \\
\hline & $\%$ & $\mathrm{~N}$ & $\%$ & $\mathrm{~N}$ & & \\
\hline & $\begin{array}{l}37 \\
63\end{array}$ & $\begin{array}{l}25 \\
43\end{array}$ & $\begin{array}{l}19 \\
81\end{array}$ & $\begin{array}{r}30 \\
121\end{array}$ & $\begin{array}{l}+18 \\
-18\end{array}$ & $\begin{array}{l}0,29 \\
0,30^{*}\end{array}$ \\
\hline $\begin{array}{l}\text { Biology } \\
\text { - ABC } \\
\text { - DEF }\end{array}$ & $\begin{array}{l}45 \\
55\end{array}$ & $\begin{array}{l}27 \\
33\end{array}$ & $\begin{array}{l}14 \\
86\end{array}$ & $\begin{array}{r}19 \\
115\end{array}$ & $\begin{array}{l}+31 \\
-31\end{array}$ & $\begin{array}{l}0,50^{*} \\
0,50^{* *}\end{array}$ \\
\hline $\begin{array}{l}\text { Bookkeeping } \\
-\mathrm{ABC} \\
-\mathrm{DEF}\end{array}$ & $\begin{array}{l}36 \\
64\end{array}$ & $\begin{array}{l}5 \\
9\end{array}$ & $\begin{array}{l}24 \\
76\end{array}$ & $\begin{array}{l}11 \\
34\end{array}$ & $\begin{array}{l}+12 \\
-12\end{array}$ & $\begin{array}{l}0,18 \\
0,18\end{array}$ \\
\hline $\begin{array}{l}\text { History } \\
- \text { ABC } \\
- \text { DEF }\end{array}$ & $\begin{array}{l}27 \\
73\end{array}$ & $\begin{array}{l}10 \\
27\end{array}$ & $\begin{array}{l}13 \\
87\end{array}$ & $\begin{array}{r}9 \\
61\end{array}$ & $\begin{array}{l}+14 \\
-14\end{array}$ & $\begin{array}{l}0,27 \\
0,28\end{array}$ \\
\hline $\begin{array}{l}\text { Typing } \\
-\mathrm{ABC} \\
-\mathrm{DEF}\end{array}$ & $\begin{array}{l}52 \\
48\end{array}$ & $\begin{array}{l}17 \\
16\end{array}$ & $\begin{array}{l}27 \\
76\end{array}$ & $\begin{array}{l}20 \\
64\end{array}$ & $\begin{array}{l}+28 \\
-28\end{array}$ & $\begin{array}{l}0,35 \\
0,42^{*}\end{array}$ \\
\hline $\begin{array}{l}\text { + Shorthand/ } \\
\text { Snelskrif } \\
\text { - ABC } \\
\text { - DEF } \\
\text { + Domestic/ } \\
\text { Science/ } \\
\text { Home } \\
\text { Economics/ } \\
\text { Needlework } \\
\text { - ABC } \\
\text { - DEF } \\
\end{array}$ & $\begin{array}{l}35 \\
65 \\
\end{array}$ & $\begin{array}{l}12 \\
22 \\
\end{array}$ & $\begin{array}{l}60 \\
40\end{array}$ & $\begin{array}{r}12 \\
8\end{array}$ & $\begin{array}{l}-13 \\
+13\end{array}$ & $\begin{array}{l}0,30 \\
0,33^{*}\end{array}$ \\
\hline
\end{tabular}

+ As these subjects can be regarded as being conceptually similar, they have been grouped together.

* p 0,05

** p $\quad 0,01$

\section{Results}

Analysis of school performance.

The findings of the study are summarised in Table 1. The table shows school symbols achieved by percentages and actual numbers of stayers and leavers as well as the percentage difference between the two groups. The last colum gives omega $(w)$ values to assess the significance of differences between the groups.

For the sake of brevity, school subjects which did not yield differences of more than $10 \%$ between the groups parent that student nurses who completed their training generally achieved higher school symbols than students who failed to complete their training. This is true for all the school subjects listed except one, namely, Shorthand/Snelskrif. In the latter case leavers performed better than stayers in that $60 \%$ of leavers achieved either A, B or C symbols compared to $47 \%$ of the stayers. Although the sample size here is too small to make reliable deductions (it will be noted that the omega value is not significant), it may be argued that persons who have done well on these subjects may find it 
relatively easy to obtain better-paying jobs in commerce or industry, for example as secretaries. Although this conclusion may be tenable, this logic does not apply to Typing or Bookkeeping which are also valued in the private sector. On both these subjects stayers achieved higher symbols than leavers.

The subject which produced the greatest difference between the two groups $(30 \%)$ was Biology which is not unexpected. It can be argued that students who did well in this subject at school are probably in a better position to cope with the subjects in the nursing curriculum than students who achieved lower symbols.

Other subjects where statistically significant differences occured are for English and the Domestic Science group of subjects. Although a relationship between high achievement on Domestic Science and completion of nursing training can be envisaged, the case of English is less clear. Apparently this result is somewhat contingent on home language in that $58 \%$ of the stayers were English-speaking and $42 \%$ were Afrikaansspeaking. For the leavers group $40 \%$ were English and $60 \%$ were Afrikaans. This gives a difference of $18 \%$ $(w=0,26, p 0,5)$. These results show that, for the group studied, English-speaking students had a greater tendency to complete their training than Afrikaansspeaking students. The nature of the data does not allow the drawings of any firm conclusions but it does point to possible biographical factors linked in home language which should be explored further.

\section{Length of service of leavers}

The second aim of the study was to establish the length of time student nurses stayed in nursing before they left. For this purpose the median length of service was calculated for a sample of 212 students who discontinued their training. The median length of service for this group was 6 months. This means that half of the students who left nursing dropped out of the course before they had completed 6 months of their training. This finding has a number of serious cost implications.

As nursing is a highly skilled profession it is unlikely that students in the firt 6 months of their training could have contributed a great deal as far as proficient nursing care is concerned. At best, such persons can be regarded as having been an "extra pair of hands" to perform relatively routine tasks only. Balanced against this are a number of costs which are incurred by hospitals to employ these persons. Consider, for example, the following costs in terms of administration and time: recruitment, selection (eg, interview, medical examination), orentation, training, salaries, accommodation, meals and usual overheads. In addition to these, there are often "invisible"' costs associated with staff turnover, such as lowered morale among persons who remain behind.

In total, it would appear that hospitals are gaining very few benefits from short tenure nurses but, indeed, are subject to a large number of expenditures which could potentially have been allocated to other more essential items.

\section{Discussion and Conclusions}

The results of this study have demonstrated that student nurses who completed their training generally performed better at school than nurses who did not complete the course. Although the differences between the two groups were not all statistically significant the results have nevertheless highlighted this trend.

It should be borne in mind, however, that the findings of the study refer to certain general trends. Therefore, no categorical statements can be made here regarding the qualities of students who should be accepted for training. For example, there are nurses who perform relatively poorly at school but who nevertheless become successful students. The contrary is also true. It is therefore advisable that nursing administrators in individual hospitals record and monitor base data such as school symbols for students. Over time a profile of students who leave nursing could be built up which could be contrasted to a profile of successful students. In this manner criteria for acceptance of nursing applicants could be developed by each hospital which could improve selection and have a substantial bearing on cost reduction and improving operational efficiency.

Finally, it should be noted that the results pertaining to this study may only be specific to the hospital in which the investigation was carried out. Therefore, further research on these variables in other hospital settings are necessary so as to broaden our knowledge of the factors leading to stability of students in the nursing profession.

\section{REFERENCES} 1. Flippo, E.B. Principles of Personnel Management Tokyo: McGraw Hill Ltd, 1976.
2. Lawshe, C.H. and Baker, P.C. Three aids in the evaluation of the significance of dif-
ferences between percentages. Educational and Psychological Measurement, 1950, 10 ,
263-270. 